\title{
PENGARUH PROFESIONALISME, KARAKTERISTIK PEKERJAAN DAN KOMITMEN ORGANISASI TERHADAP KINERJA PEGAWAI DI DINAS SOSIAL KABUPATEN LABUHANBATU UTARA
}

\footnotetext{
${ }^{1}$ Andri Junasri Tanjung, ${ }^{2}$ Muhammad Ali Imran, ${ }^{3}$ Winda Santi Dalimunthe, ${ }^{4}$ Sarifah Hanum Lubis, ${ }^{5}$ Ucok Syahputra $1,2,3,4,5$ Universitas Islam Sumatera Utara Iandri.junasri@gmail.com, ${ }^{2}$ ali.imran@gmail.com, ${ }^{3}$ winda.santi@gmail.com, ${ }^{4}$ sarifah.hanum@gmail.com, 5 ucok.syahputra@gmail.com
}

\begin{abstract}
The purpose of this research is to analyze, the influence of professionalism on the performance of employees in the Social Service Of North Labuhanbatu Regency, the influence of work characteristics on the performance of employees in the Social Service of North Labuhanbatu Regency, the influence of organizational commitment to the performance of employees in the Social Service of North Labuhanbatu Regency and the influence of professionalism, characteristics of work and organizational commitment to the performance of employees in the Social Service of North Labuhanbatu Regency. Sampling techniques in this study is total sampling, namely all employees in the Social Service Of North Labuhanbatu Regency of 42 people. Analysis techniques used are descriptive analysis methods and multiple linear regression analysis, Variable Research Results professionalism, characteristic work and organizational commitment simultaneously have a significant effect on the performance of employees in working in the Social Service North Labuhanbatu Regency, Variable professionalism partially no significant influence on the performance of employees in the Social Service North Labuhanbatu Regency, variable characterisstic work partially no significant influence on the performance of employees in the Social Service North Labuhanbatu Regency, the organizational commitment variable is partially there is a significant influence on the performance of employees in the Social Service North Labuhanbatu Regency. Professionalism, job characteristics and organizational commitment were able to explain the effect on employee performance by $61.4 \%$, while the remaining $39.6 \%$ were explained by other variables not studied in this study.
\end{abstract}

Keywords: Professionalism, Karaketerisik Work, organizational commitment, Performance..

ABSTRAK : Tujuan penelitian ini yaitu untuk menganalisis, pengaruh profesionalisme terhadap kinerja pegawai di Dinas Sosial Kabupaten Labuhanbatu Utara, pengaruh karakteristik pekerjaan terhadap kinerja pegawai di Dinas Sosial Kabupaten Labuhanbatu Utara, pengaruh komitmen organisasi terhadap kinerja pegawai di Dinas Sosial Kabupaten Labuhanbatu Utara dan Pengaruh profesionalisme, karakteristik pekerjaan dan komitmen organisasi terhadap kinerja pegawai di Dinas Sosial Kabupaten Labuhanbatu Utara. Teknik pengambilan sampel dalam penelitian ini adalah total sampling, yaitu seluruh pegawai di Dinas Sosial Kabupaten Labuhanbatu Utara yang berjumlah 42 orang. Teknik analisis yang digunakan adalah metode analisis deskriptif dan analisis regresi linear berganda, Hasil Penelitian Variabel profesionalisme, karaktersistik pekerjaan dan komitmen organisasi secara simultan berpengaruh signifikan terhadap kinerja pegawai dalam bekerja di Dinas Sosial Kabupaten Labuhanbatu Utara, Variabel profesionalisme secara parsial tidak ada pengaruh signifikan kinerja pegawai di Dinas Sosial Kabupaten Labuhanbatu Utara, variabel karakterisstik pekerjaan secara parsial tidak ada pengaruh signifikan kinerja pegawai di Dinas Sosial Kabupaten Labuhanbatu Utara, variabel komitmen organisasi secara parsial ada pengaruh signifikan kinerja pegawai di Dinas Sosial Kabupaten Labuhanbatu Utara. Profesionalisme, karakteristik pekerjaan dan komitmen organisasi mampu menjelaskan pengaruhnya terhadap kinerja pegawai sebesar 61,4\%, sedangkan sisanya $39,6 \%$ dijelaskan oleh variabel lain yang tidak dikaji dalam penelitian ini.

Kata kunci : Profesionalisme, Karaketerisik Pekerjaan, komitmen organisasi, Kinerja.. 


\section{Pendahuluan}

Pegawai juga merupakan salah satu dari beberapa jenis sumber daya utama yang harus dikelola dengan baik oleh manajemen. Sumber daya manusia merupakan faktor mutlak yang diperlukan dalam suatu organisasi, baik instansi pemerintah, perusahaan-perusahaan atau usahausaha sosial untuk mendapatkan suatu balas jasa / imbalan tertentu. Setiap organisasi membutuhkan tenaga kerja untuk dapat beroperasi dan meningkatkan kualitas produk maupun jasa. Profesi yang memberikan jasa tersebut juga dituntut mempunyai kemampuan yang cemerlang. Mengingat sumber daya manusia merupakan aset penting maka banyak hal yang perlu diperhatikan terkait dengan peningkatan kinerja.

Dinas Sosial Kabupaten Labuhanbatu Utara merupakan salah satu instansi pemerintah yang bertugas dibidang sosial masyarakat khususnya Kabupaten Labuhanbatu Utara. Dinas Sosial Kabupaten Labuhanbatu Utara sebagai instansi pemerintahan yang wajib melaksanakan tugas di bidang pelayanan masyarakat yaitu melaksanakan sebagian urusan pemerintahan daerah berdasarkan asas otonomi dan tugas pembatuan di bidang sosial dalam wilayah Kabupaten Labuhanbatu Utara. Dalam melayani kepentingan masyarakat tersebut dibutuhkan karyawan yang berkompetensi dan juga profesional dalam melakukan setiap pekerjaannya.

Berdasarkan pengertian kinerja menurut Mangkunegara (2001:67) menyebutkan kinerja adalah hasil kerja yang secara kualitas dan kuantitas yang telah dicapai oleh seorang pegawai dalam mengemban tugasnya sesuai dengan tanggung jawab yang telah diberikan kepadanya. Yang dimaksud dengan kualitas disini adalah dilihat dari segi kebersihan, kehalusan dan ketelitian dalam menjalankan tugas dan pekerjaannya. Sedangkan, yang dimaksud dengan kuantitas itu dilihat dari banyaknya jumlah pekerjaan yang harus diselesaikan oleh pegawai tersebut.

Sedangkan Gibson dalam Kasmir (2015:182) menyatakan bahwa kinerja individu adalah dasar kinerja organisasi yang sangat dipengaruhi oleh karakteristik individu, motivasi individu, pengharapan, dan penilaian yang dilakukan oleh manajemen terhadap pencapaian hasil kerja individu. Sementara itu menurut Rivai and Basri (dalam Harsuko 2011:11), menyatakan bahwa kinerja adalah hasil kerja yang dapat dicapai oleh seseorang atau kelompok orang dalam suatu perusahaan sesuai dengan wewenang dan tanggung jawab masing-masing dalam upaya pencapaian tujuan perusahaan secara ilegal, tidak melanggar hukum dan tidak bertentangan dengan moral dan etika.

Profesionalisme merupakan hal yang paling dituntut bagi seorang pegawai yang sudah bekerja. Profesionalisme berasal dari kata profesi adalah suatu pekerjaan yang membutuhkan pengetahuan, keahlian khusus (melalui persiapan dan latihan), kecakapan teknik, dan kematangan etik untuk dapat menjadi profesional.

Sedangkan profesionalimse kerja dalam penelitian ini adalah suatu kondisi terwujudnya suatu pelaksanaan kerja yang baik dan optimal oleh para pegawai. Profesionalisme sering sekali dikaitkan dengan hasil kinerja yang dicapai oleh pegawai itu sendiri. Didalam aspek muatan kinerja salah satunya yaitu aspek profesional dimana profesional yaitu individu yang dapat mengerjakan pekerjaan dengan baik, dan memberi hasil yang memuaskan. Selain itu seorang yang memiliki tingkat profesionalisme yang tinggi secara otomatis menghasilkan kinerja atau output dengan kualitas yang baik.

Berdasarkan hasil pra-survei yang dilakukan di Dinas Sosial Kabupaten Labuhanbatu Utara diperoleh hasil bahwa mayoritas pegawai di instansi tersebut memiliki tingkat profesionalisme yang cukup tinggi. Hal tersebut dapat dibuktikan dengan temuan yang diperoleh peneliti terhadap setiap pekerjaan pegawai di Dinas Sosial Kabupaten Labuhanbatu Utara memiliki dedikasi yang tinggi dalam setiap melaksanakan pekerjaannya, mampu mengambil keputusan secara baik, mampu menangani dan melayani masyarakat dengan baik, serta mampu melaksanakan setiap pekerjaan tepat waktu dengan tingkat ketelitian yang tinggi. Tetapi peneliti juga menemukan fenomena yang berhubungan dengan profesonalisme kerja pegawainya yaitu adanya pegawai yang kurang terampil dalam bekerja sehingga melakukan kesalahan-kesalahan dalam pekerjaannya. Selain itu juga ditemukannya pegawai yang bekerja tanpa target pencapaian yang telah ditetapkan sehingga menyebabkan pekerjaan yang menumpuk diatas meja kerja dan pelayanan kemasyarakat terganggu.

Kemudian peneliti juga menemukan dalam pengamatan awalnya di lingkungan Dinas Sosial Kabupaten Labuhanbatu Utara yakni 
dalam hal karakteristik pekerjaan pegawai. Menurut Panudju dalam Nabilla (2015:28), karakteristik pekerjaan menunjukkan seberapa besar pengambilan keputusan yang dibuat oleh karyawan kepada pekerjaannya, dan seberapa banyak tugas yang harus dirampungkan oleh karyawan. Sedangkan berdasarkan kesimpulan yang diperoleh dari para ahli menyebutkan karakteristik pekerjaan merupakan sifat dan tugas yang meliputi tanggung jawab, macam tugas dan tingkat kepuasan yang diperoleh dari pekerjaan itu sendiri. Dari hasil pengamatanya tersebut peneliti menemukan masih adanya pegawai yang belum memahami akan tugas dan tanggung jawabnya dalam organisasi. Serta masih terdapat pegawai yang merasa terbebani dengan beban pekerjaan ganda yang diberikan kepadanya.

Variabel berikutnya yang menjadi pengamatan oleh peneliti adalah mengenai komitmen organisasi. Berdasarkan pengertian dari Khaerul Umam (2010:259) mengartikan komitmen organisasi sebagai penerimaan yang kuat dalam diri individu terdapat tujuan dan nilai-nilai organisasi, sehingga individu tersebut akan berkarya serta memiliki keinginan yang kuat untuk bertahan di organisasi. Komitmen terhadap organisasi artinya lebih dari sekedar keanggotaan formal, karena meliputi sikap menyukai organisasi dan kesediaan untuk berusaha maksimal bagi kepentingan organisasi dalam mencapai tujuan.

Pada pengamatan awal yang dilakukan peneliti di Dinas Sosial Kabupaten Labuhanbatu Utara, peneliti melihat masih adanya sikap pegawai yang merasa pihak manajemen belum memberikan jaminan karir yang baik, ini dibuktikan dengan adanya bebeerapa pegawai cenderung bermalasmalasan, bersikap masa bodoh, tidak disiplin bahkan upaya dari segelintir pegawai yang berusaha mencari penghasilan sampingan ditempat lain.

\subsection{Batasan Masalah}

Agar permasalahan yang dikaji terarah maka permasalahan dibatasi sebagai berikut. Penelitian ini hanya membahas profesionalisme, karakteristik pekerjaan dan komitmen organisasi terhadap kinerja pegawai di Dinas Sosial Kabupaten Labuhanbatu Utara.

\subsection{Hioptesis}

Berdasarkan rumusan masalah tujuan penelitian, kajian teori, dan kerangka konseptual yang telah dikemukakan diatas, maka rumusan hipotesis penelitian ini dapat dirumuskan sebagai berikut:

1) Profesionalisme berpengaruh signifikan terhadap kinerja pegawai di Dinas Sosial Kabupaten Labuhanbatu Utara (X1-Y).

2) Karakteristik pekerjaan berpengaruh signifikan terhadap kinerja pegawai di Dinas Sosial Kabupaten Labuhanbatu Utara (X2Y).

3) Komitmen organisasi berpengaruh signifikan terhadap kinerja pegawai di Dinas Sosial Kabupaten Labuhanbatu Utara (X3Y).

4) Profesionalisme, karakteristik pekerjaan dan komitmen organisasi secara bersama-sama berpengaruh signifikan terhadap kinerja pegawai di Dinas Sosial Kabupaten Labuhanbatu Utara (X1,X2, X3-Y).

\subsection{Tujuan Penelitian}

Berdasarkan rumusan masalah penelitian sebagaimana diuraikan di atas, maka tujuan yang akan dicapai dalam penelitian ini yaitu untuk menganalisis:

1) Pengaruh profesionalisme terhadap kinerja pegawai di Dinas Sosial Kabupaten Labuhanbatu Utara.

2) Pengaruh karakteristik pekerjaan terhadap kinerja pegawai di Dinas Sosial Kabupaten Labuhanbatu Utara.

3) Pengaruh komitmen organisasi terhadap kinerja pegawai di Dinas Sosial Kabupaten Labuhanbatu Utara.

4) Pengaruh profesionalisme, karakteristik pekerjaan dan komitmen organisasi terhadap kinerja pegawai di Dinas Sosial Kabupaten Labuhanbatu Utara.

\section{Metode Penelitian}

\subsection{Populasi}

Populasi adalah wilayah generalisasi yang terdiri atas objek / subjek yang mempunyai kualitas dan karakteristik tertentu yang ditetapkan oleh peneliti untuk dipelajari kemudian ditarik kesimpulannya. Suharyadi (2004:98). Jadi populasi bukan hanya orang tetapi juga benda-benda alam yang lain. Populasi juga bukan sekedar jumlah yang ada pada objek / subjek yang dipelajari, tetapi meliputi seluruh karakteristik, sifat yang dimiliki objek / subjek itu.

Dari pengertian tersebut, maka dapat disimpulkan bahwa populasi merupakan subjek penelitian dimana pegawai yang akan dikenai 
perilaku atau dapat dikatakan sebagai keseluruhan objek penelitian yang akan diteliti. Maka yang menjadi populasi dalam penelitian ini adalah pegawai di Dinas Sosial Kabupaten Labuhanbatu Utara yang berjumlah 42 orang.

\subsection{Sampel}

Sampling adalah suatu cara yang ditempuh dengan pengambilan sampel yang benar-benar sesuai dengan keseluruhan obyek penelitian. Teknik pengambilan sampel dalam penelitian ini adalah total sampling. Total sampling adalah teknik pengambilan sampel dimana jumlah sampel sama dengan populasi, Sugiyono (2007:34). Alasan mengambil total sampling karena menurut Sugiyono jumlah populasi yang kurang dari 100 seluruh populasi dijadikan sampel penelitian semuanya.

Dengan teknik penarikan sampel secara total sampling maka sampel dalam penelitian ini adalah 40 orang pegawai dimana satu orang pimpinan tertinggi dan peneliti tidak dilakukan penelitian.

\subsection{Uji Normalitas}

Pengujian normalitas data bertujuan untuk melihat normal tidaknya sebaran data yang akan dianalisis. Model regresi yang baik adalah distribusi normal atau mendekati normal. Untuk melihat normalitas data ini digunakan pendekatan grafik yaitu Normality Probability Plot.

Menurut Santoso (2004:214), dasar pengambilan keputusan adalah:

a. Jika data menyebar disekitar garis diagonal dan mengikuti arah garis diagonal, maka model regresi memenuhi asumsi normalitas. b. Jika data menyebar jauh dari garis diagonal dan atau tidak mengikuti arah garis diagonal, maka model regresi tidak memenuhi asumsi normalitas.

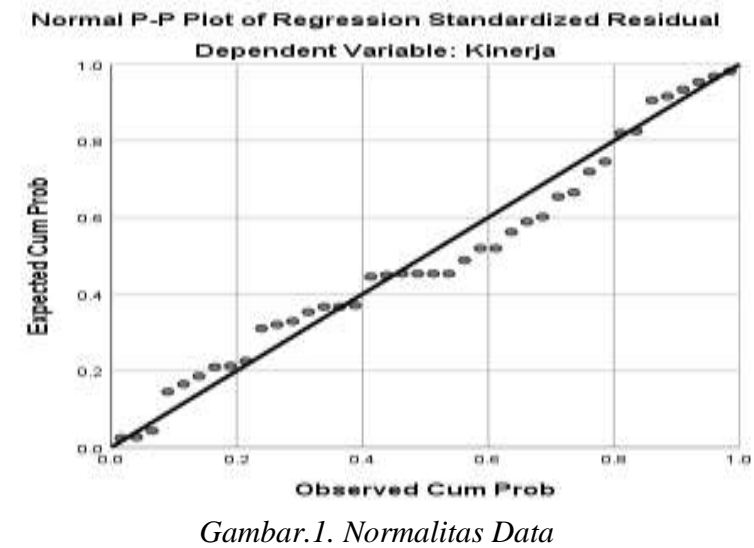

Pada output SPSS seperti gambar diatas diketahui bagian normal P-P Plot of Regresion Standardized Residual, dapat dijelaskan bahwa data-data (titik-titik) cenderung lurus mengikuti garis diagonal sehingga data dalam penelitian ini cenderung berdistribusi normal.

\subsection{Uji Multikolinearitas}

Pengujian multikolinearitas dilakukan untuk melihat apakah pada model regresi ditemukan adanya korelasi antara variabel bebas. Jika terjadi korelasi, maka dinamakan terdapat problem multikolinearitas. Cara mendeteksinya adalah dengan melihat nilai Variance Inflation Factor (VIF). Menurut Santoso (2004:203), pada umumnya jika VIF lebih besar dari 5, maka variabel bebas tersebut mempunyai persoalan multikolinearitas dengan variabel bebas lainnya.

\begin{tabular}{|c|c|c|c|c|c|c|c|c|}
\hline \multicolumn{9}{|c|}{$\begin{array}{c}\text { Tabel 1. Uji Multikolinearitas } \\
\text { Coefficients }^{\mathrm{a}}\end{array}$} \\
\hline \multirow{2}{*}{\multicolumn{2}{|c|}{ Model }} & \multicolumn{2}{|c|}{$\begin{array}{l}\text { Unstandardized } \\
\text { Coefficients }\end{array}$} & \multirow{2}{*}{$\begin{array}{l}\text { Standardized } \\
\text { Coefficients } \\
\text { Beta }\end{array}$} & \multirow[t]{2}{*}{$\mathrm{t}$} & \multirow[t]{2}{*}{ Sig. } & \multicolumn{2}{|c|}{$\begin{array}{l}\text { Collinearity } \\
\text { Statistics }\end{array}$} \\
\hline & & $\mathrm{B}$ & Std. Error & & & & Tolerance & VIF \\
\hline \multirow{4}{*}{1} & (Constant) & 3.092 & 4.150 & & .745 & .461 & & \\
\hline & Profesionalisme & .089 & .100 & .096 & .889 & .380 & .847 & 1.181 \\
\hline & Karakteristik.Pek & .159 & .134 & .144 & 1.185 & .244 & .674 & 1.484 \\
\hline & Komitmen.Org & .758 & .146 & .674 & 5.197 & .000 & .587 & 1.703 \\
\hline
\end{tabular}

a. Dependent Variable: Kinerja

Berdasarkan nilai hasil perhitungan dengan SPSS diperoleh data nilai VIF sebesar 1.181, 1.484 dan 1.703 dengan nilai toleransi 0.847 , 0.674 , dan 0.587 , hal ini menunjukkan adanya korelasi yang cukup kuat antara sesama variabel bebas, dimana semua angka VIF berada dibawah 5, hal ini menunjukan tidak terjadi multikolinearitas.

\subsection{Uji Heterokedastisitas}

Pengujian heteroskedastisitas bertujuan untuk melihat apakah dalam sebuah model 
regresi terjadi ketidaksamaan varians dari residual yang merupakan suatu pengamatan ke pengamatan yang lainnya. Jika varians dari residual yang merupakan suatu pengamatan ke pengamatan yang lain bernilai tetap, maka hasil data disebut homoskedastisitas dan jika varians berbeda atau bernilai tidak tetap maka disebut heteroskedastisitas. Model regresi yang baik adalah model yang bernilai tetap atau homoskedastisitas atau tidak terjadi heteroskedastisitas.

Menurut Santoso (2004:208), dasar pengambilan keputusannya adalah:

a. Jika pola tertentu seperti titik-titik yang ada membentuk suatu pola tertentu yang teratur, maka terdapat situasi heteroskedastisitas.

b. Jika tidak ada pola yang jelas, serta titik-titik menyebar diatas dan dibawah angka nol pada sumbu Y, maka tidak terjadi heteroskedastisitas.

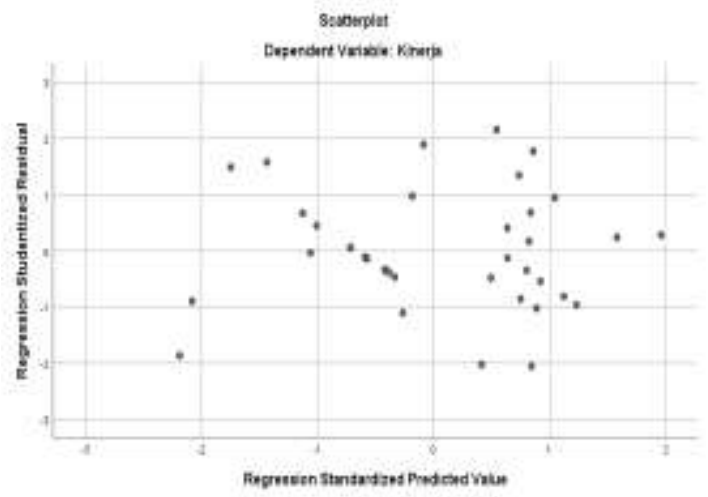

Gambar 2. Pola Scatterplot Pada Uji Heterokedastisitas

Pola Scatterplot seperti pada gambar diatas, terlihat titk-titik menyebar secara acak, tidak membentuk sebuah pola tertentu yang jelas, serta tersebar baik diatas maupun dibawah angka nol pada sumbu Y. Hal ini berarti tidak terjadi heteroskedastisitas pada model regresi pada penelitian ini, sehingga model regresi layak dipakai.

\section{Teknik Analisis Data}

\subsection{Analisis Regresi Linear Berganda}

Analisis regresi linier berganda digunakan untuk mengetahui berapa besar pengaruh variabel bebas (profesionalisme,karakteristik pekerjaan dan komitmen organisasi) terhadap variabel terikat (kinerja pegawai).

Tabel 2. Hasil Regresi Linear Berganda

\begin{tabular}{|c|c|c|c|c|c|c|c|c|}
\hline \multicolumn{9}{|c|}{ Coefficients $^{\mathrm{a}}$} \\
\hline & \multirow[t]{2}{*}{ Model } & \multicolumn{2}{|c|}{$\begin{array}{l}\text { Unstandardized } \\
\text { Coefficients }\end{array}$} & \multirow{2}{*}{$\begin{array}{l}\text { Standardized } \\
\text { Coefficients } \\
\text { Beta }\end{array}$} & \multirow[t]{2}{*}{$\mathrm{t}$} & \multirow[t]{2}{*}{ Sig. } & \multicolumn{2}{|c|}{$\begin{array}{l}\text { Collinearity } \\
\text { Statistics }\end{array}$} \\
\hline & & $\mathrm{B}$ & Std. Error & & & & Tolerance & VIF \\
\hline \multirow{4}{*}{1} & (Constant) & 3.092 & 4.150 & & .745 & .461 & & \\
\hline & Profesionalisme & .089 & .100 & .096 & .889 & .380 & .847 & 1.181 \\
\hline & Karakteristik.Pek & .159 & .134 & .144 & 1.185 & .244 & .674 & 1.484 \\
\hline & Komitmen.Org & .758 & .146 & .674 & 5.197 & .000 & .587 & 1.703 \\
\hline
\end{tabular}

Pada tabel diatas maka diperoleh hasil sebagai berikut:

$\mathrm{Y}=3,092+0,089 \mathrm{X}_{1}+0,159 \mathrm{X}_{2}+0,758 \mathrm{X}_{3}+e$

Interpretasi model tersebut sebagai berikut:

1) Nilai konstanta sebesar 2,087 menunjukkan bahwa jika variabel profesionalisme $\left(\mathrm{X}_{1}\right)$, karakteristik pekerjaan $\left(\mathrm{X}_{2}\right)$ dan komitmen organisasi $\left(\mathrm{X}_{3}\right)$ dianggap tetap, tidak mengalami perubahan atau penurunan dalam penelitian ini maka nilai kinerja pegawai $(\mathrm{Y})$ sebesar 3,092.

2) Koefisien regresi variabel profesionalisme $\left(\mathrm{X}_{1}\right)$ sebesar 0,089. Ini bermakna bahwa jika variabel profasionalisme $\left(\mathrm{X}_{1}\right)$ mengalami kenaikan sebesar satu satuan, maka akan menyebabkan kenaikan kinerja pegawai $(\mathrm{Y})$ sebesar 0,89 , dengan menganggap variabel lain konstan.

3) Koefisien regresi variabel karakteristik pekerjaa $\left(\mathrm{X}_{2}\right)$ sebesar 0,159. Ini bermakna bahwa jika variabel karakteristik pekerjaan mengalami kenaikan sebesar satu satuan, maka akan menyebabkan kenaikan kinerja pegawai (Y) sebesar 1,59, dengan menganggap variabel lain konstan.

4) Koefisien regresi variabel komitmen organisasi $\left(\mathrm{X}_{3}\right)$ sebesar 0,758 . Ini bermakna bahwa jika variabel komitmen organisasi 
mengalami kenaikan sebesar satu satuan, maka akan menyebabkan kenaikan kinerja pegawai (Y) sebesar 7,58, dengan menganggap variabel lain konstan.

Pada persamaan tersebut dapat dilihat bahwa profesionalisme, karakateristik pekerjaan dan komitemen organisasi memiliki kemampuan untuk mempengaruhi kinerja pegawa di Dinas Sosial Kabupaten Labuhanbatu Utara, profesionalisme, karakateristik pekerjaan dan komitemen organisasi mempunyai koefisien regresi positif yang membuktikan kontibusinya terhadap kinerja pegawa di Dinas Sosial
Kabupaten Labuhanbatu Utara. Hal ini menunjukkan bahwa kinerja pegawai di Dinas Sosial Kabupaten Labuhanbatu Utara dapat dipengaruhi oleh profesionalisme, karakateristik pekerjaan dan komitemen organisasi

\section{Pengujian Hipotesis}

\subsection{Pengujian Simultan}

Hasil pengujian hipotesis berpengaruh secara simultan antara profesionalisme, karakteristik pekerjaan dan komitmen organisasi terhadap kinerja pegawai dapat dilihat pada tabel dibawah ini.

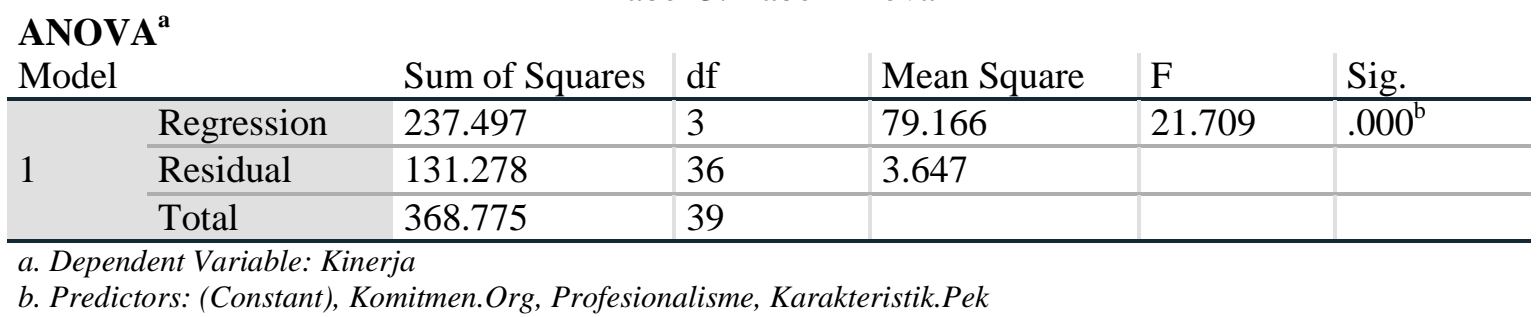

Pada tabel diatas terlihat bahwa nilai $\mathrm{F}$ hitung adalah 21,709 dan nilai signifikansi 0,000 . Dengan derajat bebasnya yaitu $\mathrm{df}_{1}=\mathrm{k}-$ $1=4-1=3$ dan $\mathrm{df}_{2}=\mathrm{N}-\mathrm{k}=40-4=36$, maka nilai F-tabel dengan tingkat kepercayaan 95\% $(\alpha: 0,05)$ adalah $\mathbf{2 , 8 7}$.

Oleh karena itu nilai F-hitung > F-tabel $(21,709>2,87)$ dan dengan nilai signifikansi $0,000<0,05$ maka Ha diterima dan Ho ditolak berarti hipotesis dalam penelitian ini yaitu bahwa profesionalisme, karaktersistik pekerjaan dan komitmen organisasi secara simultan berpengaruh signifikan terhadap kinerja pegawai dalam bekerja di Dinas Sosial Kabupaten Labuhanbatu Utara.

\subsection{Pengujian Parsial}

Berdasarkan dari tabel coefficients pada uji multikolinearitas, maka diperleh data sebagai berikut. Terlebih dahulu kita menghitung t-tabel yang akan menjadi tolok ukur pada pengujian parsial pada tiap-tiap variabel $\mathrm{x}$ terhadap variabel y.

Dengan derajat bebas pengujian (df) adalah $\mathrm{N}-\mathrm{k}=40-4=36$. Maka nilai t-tabel pada tingkat kepercayaan $95 \%(\alpha: 0,05)$ adalah 2,028 .

4.2.1. Pengaruh Profesionalisme Terhadap Kinerja

Dari tabel coefficients pada uji multikolinearitas, diperoleh hasil sebagai berikut:

\section{Coefficients $^{\mathrm{a}}$}

\begin{tabular}{|c|c|c|c|c|c|c|c|}
\hline \multirow{2}{*}{ Model } & \multicolumn{2}{|c|}{$\begin{array}{l}\text { Unstandardized } \\
\text { Coefficients }\end{array}$} & \multirow{2}{*}{$\begin{array}{l}\text { Standardized } \\
\text { Coefficients } \\
\text { Beta }\end{array}$} & \multirow{2}{*}{$\mathrm{t}$} & \multirow{2}{*}{ Sig. } & \multicolumn{2}{|c|}{$\begin{array}{l}\text { Collinearity } \\
\text { Statistics }\end{array}$} \\
\hline & B & Std. Error & & & & Tolerance & VIF \\
\hline Profesionalisme & .089 & .100 & .096 & .889 & .380 & .847 & 1.181 \\
\hline
\end{tabular}

Tabel 4. Hasil Uji Parsial $\mathrm{X}_{1}$ Terhadap Y

a. Dependent Variable: Kinerja

Berdasarkan tabel diatass diperoleh nilai t-hitung sebesar 0,889, maka nilai t-hitung $<\mathrm{t}$-tabel $(0,889<2,028)$, maka dapat disimpulkan Ho diterima dan Ha ditolak, yang artinya variabel profesionalisme secara parsial tidak ada pengaruh signifikan kinerja pegawai dalam bekerja di Dinas Sosial Kabupaten Labuhanbatu Utara.

\subsubsection{Pengaruh Karakteristik Pekerjaan Terhadap Kinerja}

Dari tabel coefficients pada uji multikolinearitas, diperoleh hasil sebagai berikut: 
Tabel Error! No text of specified style in document.. Hasil Uji Parsial $\mathrm{X}_{2}$ Terhadap Y Coefficients $^{\mathrm{a}}$

\begin{tabular}{|c|c|c|c|c|c|c|c|}
\hline \multirow{2}{*}{ Model } & \multicolumn{2}{|c|}{$\begin{array}{l}\text { Unstandardized } \\
\text { Coefficients }\end{array}$} & \multirow{2}{*}{$\begin{array}{l}\text { Standardized } \\
\text { Coefficients } \\
\text { Beta }\end{array}$} & \multirow[t]{2}{*}{$\mathrm{t}$} & \multirow{2}{*}{ Sig. } & \multicolumn{2}{|c|}{$\begin{array}{l}\text { Collinearity } \\
\text { Statistics }\end{array}$} \\
\hline & B & Std. Error & & & & Tolerance & VIF \\
\hline Karakter.Pek & .159 & .134 & .144 & 1.185 & .244 & .674 & 1.484 \\
\hline
\end{tabular}

Berdasarkan tabel diatass diperoleh nilai thitung sebesar 1,185 , maka nilai t-hitung $<\mathrm{t}$ tabel $(0,452<2,028)$, maka dapat disimpulkan Ho diterima dan Ha ditolak, yang artinya variabel karakteristik pekerjaan secara parsial tidak ada pengaruh signifikan kinerja pegawai

\subsubsection{Pengaruh Komitmen Organisasi Terhadap Kinerja}

Dari tabel coefficients pada uji multikolinearitas, diperoleh hasil sebagai berikut: dalam bekerja di Dinas Sosial Kabupaten Labuhanbatu Utara.

Tabel 6. Hasil Uji Parsial $X_{3}$ Terhadap Y Coefficients $^{\mathrm{a}}$

\begin{tabular}{|c|c|c|c|c|c|c|c|}
\hline \multirow{3}{*}{ Model } & \multicolumn{5}{|c|}{ Coefficients" } & \multirow{2}{*}{\multicolumn{2}{|c|}{$\begin{array}{l}\text { Collinearity } \\
\text { Statistics }\end{array}$}} \\
\hline & \multicolumn{2}{|c|}{$\begin{array}{l}\text { Unstandardized } \\
\text { Coefficients }\end{array}$} & \multirow{2}{*}{$\begin{array}{l}\text { Standardized } \\
\text { Coefficients } \\
\text { Beta }\end{array}$} & \multirow{2}{*}{$\mathrm{t}$} & \multirow{2}{*}{ Sig. } & & \\
\hline & B & Std. Error & & & & Tolerance & VIF \\
\hline Komitmen.Org & .758 & .146 & .674 & 5.197 & .000 & .587 & 1.703 \\
\hline
\end{tabular}

Berdasarkan tabel diatass diperoleh nilai thitung sebesar 5,197, maka nilai t-hitung > ttabel $(5,197>2,028)$, maka dapat disimpulkan Ha diterima dan Ho ditolak, yang artinya variabel komitmen organisasi secara parsial ada pengaruh signifikan kinerja pegawai dalam bekerja di Dinas Sosial Kabupaten Labuhanbatu Utara.

\section{Model Summary}

\begin{tabular}{ll|l|l|l} 
Model & $\mathrm{R}$ & R Square & Adjusted R Square & $\begin{array}{l}\text { Std. Error of the } \\
\text { Estimate }\end{array}$ \\
\hline 1 & $.803^{\mathrm{a}}$ & .644 & .614 & 1.90961 \\
\hline a. Predictors: (Constant), Komitmen.Org, Profesionalisme, Karakteristik.Pek &
\end{tabular}

Maka pada tabel diatas menunjukan nilai Adjusted $\mathrm{R}^{2}$ adalah $61,4 \%$ variabel kinerja pegawai di Dinas Sosial Kabupaten Labuhanbatu Utara dapat dijelaskan oleh variabel profesionalisme, karakteristik pekerjaan dan komitmen organisasi sedangkan sisanya 39,6\% tidak dilakukan dalam penelitian ini.

\section{Kesimpulan}

Berdasarkan pada analisis dan evaluasi data di atas, maka dapat ditarik kesimpulan dari penelitian ini sebagai berikut:

\subsection{Pengujian Koefisien Determinasi}

Uji determinan adalah untuk mengetahui seberapa besar pengaruh variabel independen terhadap variabel dependen. Untuk melihat hasil uji determinan maka dapat diketahui nilai $\mathrm{R}$ Square atau koefesien determinasi dan dapat dilihat dibawah ini. Untuk variabel independen lebih dari dua sebaiknya menggunakan nilai Adjusted $\mathrm{R}^{2}$.

Tabel 7. Tabel Model Summary

1) Variabel profesionalisme, karaktersistik pekerjaan dan komitmen organisasi secara simultan berpengaruh signifikan terhadap kinerja pegawai dalam bekerja di Dinas Sosial Kabupaten Labuhanbatu Utara.

2) Variabel profesionalisme secara parsial tidak ada pengaruh signifikan kinerja pegawai di Dinas Sosial Kabupaten Labuhanbatu Utara.

3) Variabel karakterisstik pekerjaan secara parsial tidak ada pengaruh signifikan kinerja pegawai di Dinas Sosial Kabupaten Labuhanbatu Utara. 
4) Variabel komitmen organisasi secara parsial ada pengaruh signifikan kinerja pegawai di Dinas Sosial Kabupaten Labuhanbatu Utara.

\section{DAFTAR PUSTAKA}

Adawiyah, R., \& Siswanto, S. (2015). Stres Kerja, Pengaruhnya Terhadap Kinerja Karyawan Dengan Kepuasan Kerja Sebagai Variabel Mediasi.

Aufan, Y. (2014). Analisis Pengaruh FaktorFaktor Karakteristik Pekerjaan Terhadap Kinerja Karyawan di PT Chevron Pacific Indonesia Departemen PG \& T Minas.

Bangun, W. (2014). Manajemen Sumber Daya Manusia. Jakarta: Erlangga.

Chaplin. (2011). Kamus Lengkap Psikologi. Jakarta: Rajawali Pers.

Dermawan, D. (2013). Prinsip-Prinsip Perilaku Organisasi. Surabaya: PT. Temprina Media Grafika.

Djastuti, I. (2011). Pengaruh Karakteristik Pekerjaan Terhadap Komitmen Organisasi karyawan Tingkat Managerial Perusahaan Jasa Konstruksi Di Jawa Tengah. Jurnal Bisnis dan Akuntansi.

Handaru, dkk. (2013). Penagruh Karaktersitik Pekerjaan dan Kompensasi Terhadap Komitmen Organisasi pada PT "X" Jakarta. Jurnal Riset Manajemen Sains Indonesia.

Harefa, A. (2014). Membangkitkan Etos Profesionalisme. Jakarta: Gramedia Pustaka Utama.

Harsuko, R. (2011). Mendongkrak Motivasi dan Kinerja: Pendekatan. Pemberdayaan SDM. Malang: UB Press.

Hasibuan, M. S. (2010). Manajemen Sumber Daya Manusia. Jakarta: PT. Bumi Aksara.

Hasibuan, M. S. (2013). Manajemen Sumber Daya Manusia. Jakarta: PT. Bumi Aksara.

Hasibuan, M. S. (2014). Manajemen Sumber Daya Manusia. Cetakan Ke Empat Belas. Jakarta: Bumi Aksara.

Kasmir. (2015). Manajemen Sumber Daya Manusia (Teori dan Praktek). Jakarta: Raja Grafindo Persada.

Kharis, I. (2010). Pengaruh Komitmen Organisasional dan Kepuasan Kerja Terhadap Kinerja Guru SMA Negeri 3 Bandung. Jurnal Administrasi Bisnis.

Kurniawan. (2013). Pengaruh Kompetensi Pedagogik dan Kompetensi Profesional Guru. Jakarta: Universitas Pendidikan Indonesia .

Lubis, A. F., \& Syahputra, A. (2008). Pedoman Penulisan Proposal dan Tesis. Medan:
Program Magister Akuntansi Sekolah Pascasarjana USU.

Lubis, S. K. (2000). Hukum Ekonomi Islam. Jakarta: Sinar Grafika.

Lubis, S. K., \& Wadji, F. (2012). Hukum Ekonomi Islam. Jakarta: Sinar Grafika.

Luthans, F., \& Jonathan, P. D. (2014). Manajemen Internasional: Budaya, Strategi dan Perilaku. Edisi Ke Delapan. Buku Ke Dua. Jakarta: Salemba Empat.

Mangkunegara, A. P. (2010). Manajemen Sumber Daya Manusia Perusahaan. Bandung: PT. Remaja Rosdakarya.

Moorhead, G., \& Griffin, R. W. (2013). Perilaku Organisasi. (Terjemahan). Jakarta: Salemba Empat.

Nabila. (2015). Pengaruh Karakteristik Pekerjaan Dan Konflik Peran Ganda Terhadap Kepuasan Kerja. Lampung.

Nimran, U. (1997). Perilaku Organisasi. Surabaya: Citra Media.

Oerip, P. F., \& Utomo, T. (2012). Mengatasi Krisis Manusia di Perusahaan. Jakarta: Grasindo.

Prihantoro, A. (2015). Pengaruh Motivasi Kerja, Disiplin Kerja, Lingkungan Kerja dan Komitmen Terhadap Kinerja Karyawan. Jurnal EMBA.

Purba, M. W. (2018). Pengaruh Profesionalisme Dan Konflik Peran Ganda Terhadap Kinerja Karyawan Pada Dinas Perdagangan dan Perindustrian Kabupaten Langkat.

Purwono. (2013). Profesi Pustakawan Menghadapi Tantangan Perubahan. Yogyakarta: Graha Ilmu.

Putu, N. K., \& I Wayan, S. (2017). Pengaruh Kompetensi Karyawan, Motivasi Kerja, Komitmen Organisasi, Kemampuan Teknik Personal Terhadap KInerja Sistem Informasi Akuntansi. E-Jurnal Akuntansi Universitas Udayana.

Rivai, V. (2010). Manajemen Sumber Daya Manusia untuk Perusahaan dari Teori ke Praktik. Jakarta: PT. Raja Grafindo.

Rivai, V., \& Sagala, E. (2013). Manajemen Sumber Daya Manusia untuk Perusahaan. Jakarta: Rajawali Pers.

Robbins, S. P., \& Coulter, M. (2010). Manajemen Edisi Kesepuluh. Jakarta: Erlangga.

Robbins, S. P., \& Judge, T. A. (2011). Perilaku Organisasi. Jakarta: Salemba Empat.

Sandi, N. (2011). Employee Engagement: Anteseden dan Konsukuensi. Semarang. 
Sari, M. (2017). Pengaruh Profesionalisme Kerja Dan Kompensasi Terhadap Kinerja Pegawai PT. Bank Syariah Mandiri Kantor Cabang Palembang.

Sedarmayanti. (2010). Sumber Daya Manusia dan Produktivitas Kerja. Cetakan Kedua. Bandung: Mandar Maju.

Sugiyono. (2007). Statistika Untuk Penelitian. Bandung: Alfabeta.

Sugiyono. (2014). Metode Penelitian Pendidikan Pendekatan Kuantitatif, Kualitatif, dan $R \& D$. Bandung: Alfabeta.

Suharyadi, P. S. (2004). Statistika Untuk Ekonomi dan Keuangan Modern, Buku Kedua. Jakarta: Bumi Aksara.

Sutanto, E. M., \& Ratna, A. (2015). Pengaruh Komitmen Organisasional Terhadap Kinerja Karyawan Berdasarkan Karakteristik Individual. Jurnal Bisnis dan Manajemen.

Triton. (2006). SPSS 12.00 Terapan Riset Statistik Parametrik. Yogyakarta: Andi.

Umam, K. (2010). Perilaku Organisasi. Bandung: Pustaka Setia.

Veithzal, R. (2011). Manajemen Sumber Daya Manusia untuk Perusahaan, dari Teori ke Praktik. Jakarta: Raja Grafindo Persada.

Veithzal, R. (2014). Manajemen Sumber Daya Manusia untuk Perusahaan. Edisi Ke Enam. Depok: PT. Raja Grafindo Persada.

Wibowo. (2011). Manajemen Kinerja. Edisi Ketiga. Jakarta: PT. Raja Grafindo.

Wirjayanti, F. (2014). Analisis Profesionalisme Pegawai Dinas Sosial Kota Pekanbaru. Riau.

Yahya, K. K. (2009). Linking organizational Structure, Job Characteristic and Job Performance Construct: A Proposed Framework. International Journal of Business and Management. 